\title{
Implementation Gap of Social Forestry Policy: The Case of HKm Beringin Jaya and HTR Hajran
}

\author{
Budi $^{1^{*}}$, Hariadi Kartodihardjo ${ }^{2}$, Bramasto Nugroho ${ }^{2}$, Rina Mardiana ${ }^{3}$ \\ 'Graduate Program of Forest Management Science, Faculty of Forestry and Environment, IPB University, Academic Ring \\ Road, Campus IPB Dramaga, Bogor, Indonesia 16680 \\ ${ }^{2}$ Department of Forest Management, Faculty of Forestry and Environment, IPB University, Academic Ring Road, Campus IPB \\ Dramaga, Bogor, Indonesia 16680 \\ ${ }^{3}$ Departemen of Communication Science and Community Development, Faculty of Human Ecology, Kamper Road, Campus \\ IPB Dramaga, Bogor, Indonesia 16680
}

Received July 7, 2020/Accepted December 12, 2020

\begin{abstract}
The current social forestry policy is considered to accelerate the issuance of social forestry licences, but after the licence is obtained, various difficulties and obstacles are still experienced by licence holder community to achieve the objective of social forestry policy. For this reason, this study questions who is actually stakeholder or party stipulated in social forestry regulation to carry out social forestry and facilitate community to overcome the difficulties and obstacles they experienced. This study aims to analyze the implementation gap of social forestry policy towards those stipulated in social forestry regulation compared with their implementation in the field. This research was conducted at HKm Beringin Jaya and HTR Hajran. The results show that three groups of actors are stipulated in social forestry regulation, namely community with their rights and obligations, central and regional governments with their authorities and related stakeholders to support the implementation of social forestry. In two research locations, implementation gap of social forestry policy toward three groups of actors occurred in the field. The rights that can be obtained and the obligations that must be fulfilled by licence holder communities are mostly facilitated by non-governmental organizations and are influenced by the networking capacity of the community. The authority of the central and local governments to facilitate the community is not functioning adequately at the field level due to the separate political system and authority between the central and regional governments. The involvement of other related stakeholders is considered low because of their interests that must be accommodated and requiring the capacity of the community to access stakeholders.
\end{abstract}

Keywords: community, institution, government, capacity.

*Correspondence author, email: budickr@yahoo.com

\section{Introduction}

Social forestry policy and its instruments provides legal right for communities to manage state forest resources which is granted through social forestry licence scheme. Policy instruments are defined as a way to change the behaviour of a person or a community that is embedded in a strategy, program, method or tool to carry out policy (Kartodihardjo, 2017a). One of the policy instruments to implement social forestry is the Minister of Environment and Forestry Regulation Number P.83/Menlhk/Setjen/ Kum.1/10/2016 as the guide in granting management rights, licence, partnerships and customary forests of social forestry. The regulation is aimed to resolve tenure and justice issues for local and customary communities inside or around state forest area in the context of community welfare and preservation of forest functions.

Two main phases in social forestry licence scheme are the pre-licence and post-licence phase. The pre-licence phase is the phase for community to proposes a licence to the government until the social forestry licence is issued. The post-licence phase is the phase after obtaining a social forestry licence, where the community can legally utilize or manage the licence area through productive economic activities to produce goods or environmental services that provide income improvement and other benefits. Previous study on social forestry scheme showed that various difficulties and obstacles experienced by the community in proposing licence and particularly after social forestry licence is obtained (Syafitri, 2010; Ardi, 2011; Kartodihardjo et al., 2011; de Royer et al., 2015; de Royer \& Juita, 2016). Nevertheless, the current social forestry policy has been considered to accelerate the issuance of social forestry licence. It is indicated by the data of state forest area that have been granted under social forestry licenses, which increased from 0.3 million ha at the end of 2016 (MoEF, 2017), 2.0 million ha in October 2018 (Agung et al., 2018), 
2.2 million ha in April 2019 (Santoso, 2019) and increased rapidly to 4.0 million ha at the end of December $2019^{1}$. This acceleration is also supported by other policy instruments, namely the social forestry acceleration driving team (Tim Penggerak Percepatan Perhutanan Sosial/TP2PS) consisting of various stakeholders and the use of internet technology with the application of integration and navigation systems (Sistem Integrasi dan Navigasi/SINAV) (Supriyanto, 2019). In several licence holder communities, the implementation of social forestry policy is considered to have been successful (Supriyanto et al., 2018; Santoso, 2019). Basrin (2017) stated, although the current social forestry policy is taking place, the difficulties and obstacles are still experienced by the licence holder community, particularly to achieve income improvement through productive economic acitivities in the post-licensing phase. Data presented at December 2019 showed that out of 6,411 communities or farmer groups holding social forestry licences, 5,873 have formed social forestry business groups. As many as $59 \%$ of these business groups are categorized as early stage groups who are just starting their business (Supriyanto, 2019).

Therefore, in order for difficulties and obstacles experienced by the communities holding social forestry licence to be resolved, whether in the pre-licence or postlicence phase, acctually who are stakeholders or parties stipulated in the social forestry regulation that are given the authority to implement social forestry policy that can assist or facilitate the community? What are the authorities given to these stakeholders or parties to implement social forestry policy so that the community can overcome the difficulties and obstacles they are experiencing? How are these authorities exercised at the implementation level? Whether in accordance with what are stipulated in the regulation or not? These questions lead to whether there are implementation gaps of social forestry policy by stakeholders or parties that are stipulated in the regulation to implement social forestry policy. If there are gaps in the implementation of social forestry policy, what factors cause these gaps?

Social forestry policy is a policy set by the central government -in this case the Ministry of Environment and Forestry- to be implemented at the local level. Therefore, the implementation of social forestry policy certainly involves a number of parties or institutions ranging from central government to local level in the district. The difficulties and constraints experienced by the community when proposing a licence and after obtaining a social forestry licence are early indication to policy problems when implemented at the local level caused by various factors. Kartodihardjo (2017b) stated that policy problems are not inherent in the objects but in the human behaviour caused by factors, which are controlled through policy solutions. Moreover Kirsop-Taylor (2018) stated the need to focus on people (individuals and organizations) as a unit of analysis. One of them is street level bureaucrats that influences policy implementation. Thus, the research aims is to analyzed implementation gap which is focussed to stakeholders or parties stipulated in social forestry regulation compared to their implementation in the field. The results of the study describe the implementation gaps of social forestry policy and the factors that cause implementation gaps that can be used to improve the implementation of social forestry policy in the future.

\section{Methods}

The research was divided into two phases including documents study of social forestry regulation and field study to explore how its implementation in the field. The document study was carried out by conducting qualitative content analysis (Titscher et al., 2009) of the narrative of social forestry regulation. The social forestry regulation analyzed is the regulation of the Minister of Environment and Forestry Number P.83/Menlhk/Setjen/Kum.1/10/2016. The documentary study was conducted in Room A3 of the Department of Forest Management, Faculty of Forestry IPB in December 2017. The field study to explore its implementation in the field was carried out in Beringin Jaya Community Forest (Hutan Kemasyarakatan/HKm), Tanggamus District, Lampung Province and Hajran People's Forest Plantation (Hutan Tanaman Rakyat/HTR), Batanghari District, Jambi Province, from August to December 2018. The research purposively selected the HKm Beringin Jaya and HTR Hajran due to those communities have obtained social forestry licence and currently are utilizing and managing the licence areas. Apart from being recommended by key informants at the Kehati Foundation and the Ministry of Environment and Forestry, the two licence-holding communities were considered to have met the criterias to be used as research case. These criteria are: (1) the community has obtained a social forestry licence, (2) the community is carrying out activities to utilize or manage social forestry licence area, (3) the community has produced timber or non-timber forest products from social forestry licence area and (4) the community has obtained a loan to support their activities to manage licence area from the Ministry of Environment and Forestry and or other financial institutions.

The method used is to compare the stakeholders or parties stipulated in social forestry regulation to carry out social forestry policy with their implementation in the field. This method is stated by Birner (2000) as an ex-post analysis or retrospect (Dunn, 2003; Suharto, 2010) as an evaluative model by evaluating the impact or implementation of a policy. In order to conduct this method, research adopts the stages stated by Dunn (2003) to analyze the gap in the implementation of a policy. These stages include: 1) identification of stakeholders or parties related to implementation of social forestry policy, 2) identification of the rights, obligations, roles and responsibilities of stakeholders or parties based on regulation, 3) identification the realization or implementation of the roles of those stakeholders or parties at the study site, 4) contrasting the assumptions written in the regulation with the assumptions of the implementation of the regulation at the study site, 5)

${ }^{1}$ Stated by Supriyanto (2019) titled Social Forestry Review 2019: Performance Records, Numbers and Pictures, at https://www.facebook.com/bambang.supriyanto.1048/posts/10216010171747607, downloaded on January 9, 2020. 
analyzing the extent of the gap between assumptions written in the regulation and implementation at the study site, and 6) synthesizing the formulation of the problem.

The first and second stages were carried out through document study using qualitative content analysis of the narrative of social forestry regulation. Research data obtained through documentation study include: 1) the stakeholders or parties stipulated in the social forestry regulation that are given the authority to implement social forestry policy, and 2) the authorities given to stakeholders or parties stipulated in social forestry regulation to implement social forestry policy. The third and fourth stages were carried out through field study at research location. Research data obtained through field study include: 1) how the authorities given to those stakeholder or parties are exercised at the implementation level? 2) are the authorities given to those stakeholders or parties in accordance with those stipulated in social forestry regulations or not? In the fifth stage, research data obtained through documentation study are compared with the results of field study to obtain the level of conformity between those are stipulated in social forestry regulation and implementation in the field. The higher the level of conformity between those stipulated in the social forestry regulation and field implementation, the lower the implementation gap, and vice versa. In the sixth stage, the research synthesizes and formulates problems related to implementation gap of social forestry policy, the factors that cause implementation gap of social forestry policy and suggestions for improving the implementation of social forestry policy in the future.

Variables, data, and indicators for implementation gap of social forestry policy for stakeholders or institutions stipulated in social forestry regulation are shown in Table 1.

To obtain research data through field study, this research applied three techniques including: 1) in-depth interviews with key informants, 2) participatory field observations, and 3) documentation studies. In-depth interview is intended to reveal who are stakeholders or institutions that facilitate the community to obtain social forestry licence and facilitate their activities in managing the licence area in producing goods or environmental services that provide income improvement for licence holder community. To confirm the data obtained from in-depth interview, this research applied field participatory observations to HKm Beringin Jaya and HTR Hajran licence area, observing the activities of community members in managing the licence areas and collecting written documents related to the implementation of social forestry by HKm Beringin Jaya and HTR Hajran communities. These documents contain data and information that explains the proposing license, issuing license, documents of organization or groups holding social forestry license, legality of organization or groups, cooperation or partnership documents, the general work plan, the annual work plan, and other documents. Key informants interviewed related to the implementation of social forestry policy in HKm Beringin Jaya and HTR Hajran are shown in Table 2.

\section{Results and Discussion}

The history of HKm Beringin Jaya and HTR Hajran licence Beringin Jaya is the name of the Farmer Group Association which consists of Lestari Jaya Farmers Group 1 to 8 . The number of members is 551 households who come from Margoyoso Village, Sumberejo District and Talang Beringin Village, Pulau Panggung District, Tanggamus Regency, Lampung Province. The initiation of the HKm licence proposal was carried out when the non-governmental organization of LCW Lampung brought information about the HKm scheme to community. This information was followed up by community leaders to invite all community members who had utilized state forest land in the Mount Tanggamus Protected Forest. The proposal for the HKm Beringin Jaya licence refers to the Minister of Forestry Regulation Number P.88/Menhut-II/2014 which was proposed through the district forestry office then to the Ministry of Forestry in 2010. The HKm Working Area (Penetapan Area Kerja) is issued by the Ministry of Forestry through a Decree Number SK. 885/Menhut-II/2013 dated 11 December 2013. On 30 December 2014, the Bupati of Tanggamus issued the $\mathrm{HKm}$ licence for Beringin Jaya through Letter Number B.465/34/II/2014. HKm Beringin Jaya obtained licence area in the protected forest area of Mount Tanggamus Register 30 covering an area of 871 ha (5.8\% of the 15,060 ha of total areas) consisting of 840 parcels bordering community settlements for members of HKm Beringin Jaya. Before the licence was obtained, most of the community members of HKm Beringin Jaya had used the protected forest area of Mount Tanggamus (KORUT, 2017) by cultivating coffee plants mixed with other plants in the form of agroforest coffee. After obtaining the HKm licence, the Beringin Jaya HKm community was facilitated by non-governmental organization of KORUT to utilize and

Table 1 Variables, data, and indicators of the implementation gap of social forestry policy in HKm and HTR scheme

\begin{tabular}{|c|c|c|}
\hline Research variables & Research data & Indicators of implementation gap \\
\hline $\begin{array}{l}\text { Implementation gap } \\
\text { of social forestry } \\
\text { policy in HKm and } \\
\text { HTR Schemes }\end{array}$ & $\begin{array}{l}\text { 1. Stakeholders or institutions stipulated } \\
\text { in social forestry regulation that are } \\
\text { given the authority to implement social } \\
\text { forestry policy } \\
\text { 2. The authorities given to stakeholders or } \\
\text { institutuons stipulated in social forestry } \\
\text { regulation to implement social forestry } \\
\text { policy } \\
\text { 3. The authorities given to stakeholdes or } \\
\text { institutions that are exercised at } \\
\text { implementation level }\end{array}$ & $\begin{array}{l}\text { The conformity between stakeholders or } \\
\text { institutions and their authorities which are } \\
\text { stipulated in social forestry regulation compared } \\
\text { with its implementation in the field. The higher } \\
\text { the level of conformity between those stipulated } \\
\text { in the social forestry regulation and field } \\
\text { implementation, the lower the implementation } \\
\text { gap, and vice versa. }\end{array}$ \\
\hline
\end{tabular}


Table 2 Key informants related to implementation of HKm Beringin Jaya and HTR Hajran

\begin{tabular}{|c|c|c|}
\hline Groups of key informants & HKm Beringin Jaya & HTR Hajran \\
\hline $\begin{array}{l}\text { Community licence } \\
\text { holder }\end{array}$ & $\begin{array}{l}\text { 1. Head and management of HKm } \\
\text { Beringin Jaya } \\
\text { 2. Head of farmer group of Lestari Jaya } 1 \\
\text { to } 8 \\
\text { 3. } 79 \text { members of HKm Beringin Jaya } \\
\text { were selected purposively } \\
\text { 4. Woman farmer group } \\
\text { 5. Ecotourism farmer group }\end{array}$ & $\begin{array}{l}\text { 1. Head and management of four cooperatives of } \\
\text { HTR Hajran: Serengam Betuah, Mpang } \\
\text { Gagah, Bagan Rajo and Khayangan Tinggi } \\
\text { 2. } 33 \text { members of Serengam Betuah Cooperative }\end{array}$ \\
\hline Local goverment & $\begin{array}{l}\text { 1. Head of Margoyoso Village } \\
\text { 2. Protected Forest Management Unit of } \\
\text { Kota Agung Utara } \\
\text { 3. Social forestry acceleration working } \\
\text { group at provincial (Pokja PPS) }\end{array}$ & $\begin{array}{l}\text { 1. Head of Hajran Village } \\
\text { 2. Production Forest Management Unit of } \\
\text { Baranghari } \\
\text { 3. Social forestry acceleration working group at } \\
\text { provincial level }\end{array}$ \\
\hline Central goverment & $\begin{array}{l}\text { Watershed and Protection Forest } \\
\text { Management Office in Lampung } \\
\text { (technical implementation unit of MoEF) }\end{array}$ & $\begin{array}{l}\text { Production forest management office in Jambi } \\
\text { (technical implementation unit of MoEF) }\end{array}$ \\
\hline $\begin{array}{l}\text { Related } \\
\text { stakeholders }\end{array}$ & $\begin{array}{l}\text { Konsorsium Kota Agung Utara } \\
\text { (KORUT)-non government organization }\end{array}$ & $\begin{array}{l}\text { 1. Aliansi Masyarakat Peduli Hutan dan Lahan } \\
\text { (AMPHAL)-non government organization } \\
\text { 2. Director and staffs of PT Sanak Rimba } \\
\text { Sejahtera (Partner company of HTR Hajran) }\end{array}$ \\
\hline
\end{tabular}

manage the HKm licence area.

The proposal for HTR Hajran licence was initiated jointly between the community of Hajran Village and the nongovernmental organization of AMPHAL (Aliansi Masyarakat Peduli Hutan dan Lahan) when the community development activities carried out previously had ended. The state forest area proposed for the HTR licence area is a production forest containing old forest stands. It is $20 \mathrm{~km}$ from the community settlement of Hajran Village and borders to the Bukit Duabelas National Park. Before the HTR licence was obtained, only a few community members used the state forest area for local rubber plantations, which came from Hajran Village and other villages. The proposed HTR license began in 2012 based on the Minister of Forestry Regulation Number P.31/Menhut-II/2013. It was proposed to the district forestry office, followed up by the issuance of indicative license area for the Hajran HTR development area by the Ministry of Forestry in 2014. The transition of authority in forestry sector from district government to provincial government so that HTR licence proposal is re-submitted to forestry office at provincial government. The proposal for the HTR Hajran licence was facilitated by AMPHAL and the technical implementation unit of MoF. HTR License was issued by the Provincial Integrated Investment and Licensing Services Board in 2016 for 4 notary-acting cooperatives, in a production forest area of 1,272.59 ha for 161 members. After obtaining the licence, licence area is managed under a partnership scheme with a partner company, namely PT Sanak Rimba Sejahtera. With that, the utilization and management of the licence area was carried out entirely by partner company, while members of the Hajran HTR cooperative are only involved as workers in the initial development activities of the HTR licence area.

General provision of social forestry scheme Results of content analysis on the narrative of social forestry regulation show that stakeholders or parties stipulated in social forestry regulation to carry out the implementation of social forestry policy particularly in HKm and HTR schemes are community, government (central-regional) and related stakeholders. The authorities stipulated in the social forestry regulation for these stakeholders or actors are: 1) the rights and obligations of the community in implementing social forestry policy, 2) works or activities that are the authorities of the government (central-regional) to grant social forestry licence to community, to facilitate community and to supervise the use of licence area by the community, and 3) activities or work that can be carried out by related stakeholders to facilitate community in implementing social forestry policy. Before examining the implementation gap of those actors stipulated in social forestry regulation, there is a narrative concerning about general provisions that bind all social forestry schemes. Found 7 narratives regulate the general provisions of social forestry licence area as shown in Table 3 .

The narrative of social forestry regulation shown in Table 3 is the result of content analysis of social forestry regulation which then explored at its implementation in the field. Information about the implementation of those narratives in the field were obtained from key informants of the management and community members of HKm Beringin Jaya and HTR Hajran. The results showed that the Forest Management Unit (FMU) has not optimally exercised its authority as a forest area management institution at the site level closest to the community in relation to the implementation of social forestry policy. The utilization and management of the licence area has not yet referred to the forest area management plan prepared by the FMU of Kota Agung Utara in Tanggamus Regency. The FMU of Batanghari in Batanghari Regency does not even have a forest area management plan. With these conditions, communities of HKm Beringin Jaya and HTR Hajran discussed more of the problems they experienced and possible solutions in utilizing or managing the social forestry license area with other stakeholder than with the FMU. FMU is not yet fully to be Intermediate Organizations or Agencies 
Table 3 Conformity on general provisions of social forestry scheme stated in regulations compared with implementation level

\begin{tabular}{lll}
\hline \multirow{2}{*}{ Narrative in regulation } & \multicolumn{2}{c}{ HKm Beringin Jaya } \\
\cline { 2 - 3 } & \multicolumn{1}{c}{ Implementation level ${ }^{\mathrm{a}}$} \\
\hline The proposing location is in one & In accordance with the regulation of & \multicolumn{1}{c}{ HT accordance with the regulation } \\
landscape, preferably listed in Indicative & Minister of Forestry Number & of Minister of Forestry Number \\
Map of the Social Forestry Area & $\begin{array}{l}\text { P.88/Menhut-II/2014, area for HKm } \\
\text { licence determined by Ministry of }\end{array}$ & $\begin{array}{l}\text { P.31/Menhut-II/2013, area for HTR } \\
\text { licence determined by Ministry of }\end{array}$ \\
& Forestry & Forestry \\
Obtain assistance to improve the proposal, & NGO & NGO
\end{tabular}

in case the proposal is returned due to lack of proposed administrative requirements.

In the event that FMU already has a LongTerm Forest Management Plan and is already operational, proposal outside the Indicative Map of the Social Forestry Area may refer to the Plan of FMU.

List of names of local communities as prospective group members in the social forestry licence scheme known by the village head.

General description of the region, including the physical condition, socioeconomic, and its potential.

Maps of proposed location is in written documents and electronic copy.

Propose a licence request to the minister of environment and forestry or governor (if the province concerned has included social forestry in regional medium-term development plan or a governor's regulation and has its budget in the regional revenue and expenditure budget).
FMU Kota Agung Utara already has a long-term forest management plan, but the utilization and or

management of HKm Beringin Jaya has not fully referred to the Plan of FMU

In accordance

In accordance

In accordance, continued with the making of the Persil Map, signed by the head of FMU

In accordance with regulation of Minister of Forestry Number P.88/Menhut-II/2014, HKm license issued by the Bupati of Tanggamus, social forestry was inserted into Provincial Medium-Term Development Plan Year 2019-2024
FMU Batanghari has not Longterm Forest Management Plan

In accordance

In accordance

In accordance

Transition period of withdrawal of authority on forestry affairs to the province, licence issued by the Head of Regional Investment Board and Integrated Licensing Service of Jambi Province, social forestry has not been inserted in Provincial Medium-Term Development Plan or Governor's Regulation

\footnotetext{
${ }^{\text {a }}$ Some implementations of the regulatory narrative still follow the previous regulation.
}

(Frank \& Bory, 2015), Implementation Support Centre (PEW, 2017), or front-line agencies (Kirsop-Taylor 2018). The skills or expertise and quality of the people who work at the Intermediate Agency are very important in determining acceptance and receptivity in implementing a policy. The person or actor must have a unique identity, have innate personality characteristics (Robert \& King, 1996). Furthermore, Robert and King (1996) stated, including being very intuitive, critical analytical thinkers, instigators (influencers) constructive social action, well-integrated personality, highly developed ego, high leadership level, and above-average creative potential.

The next results shown in Table 3 is obtained by comparing the results of the content analysis of social forestry regulations with written documents from the provincial government. The results showed that Lampung provincial government has inserted social forestry in the 2019-2024 Regional Medium-Term Development Plan (Rencana Pembangunan Jangka Menengah Daerah/RPJMD), while Jambi Province has not inserted it in RPJMD or stated in a governor's regulation. By not inserting social forestry in the RPJMD or not yet stated in a governor's regulation, it has implications for weak support for the implementation of social forestry policy from regional government as outlined in regional policy instruments (decisions, organization or structure, human resources, budgets and programs). This situation was stated by Sausman et al. (2016) as local universality. Social forestry policy formulated at national level may face the challenge of ensuring some consistency in delivery at subnational level, due to the subnational level has some separate degree of political authority (Norris et al., 2014). In this situation, the national or central government should respond to this reality, especially when the situation occurs, which is hidden from the view of the policy-making authority. Hudson et al. (2019) emphasized that, although governance is concentrated centrally or separately, policy implementation is highly dependent on local context. Thus, the provincial, district and village governments have an important role in determine the licence holder to achieve the objectives of social forestry policy in their areas.

The community licence holder and their rights and obligations in implementing social forestry policy The results of content analysis of social forestry regulation found 
20 narratives addressing the rights that can be obtained by HKm and HTR licence holder communities. The criteria regarding the rights of community in implementing social forestry policy particularly in HKm and HTR scheme is narrative in the social forestry regulation that address what rights of community when community implements social forestry policy. The rights of community are then seen how their implementation in the field in HKm Beringin Jaya and HTR Hajran. Implementation criteria in the field are what rights have been obtained and which have not been obtained by the community when implementing the HKm and HTR schemes. The entire narrative is then viewed its implementation in the field by confirming to management and community members who hold the licence, verifying to stakeholders related to the rights of community and conducting participatory observations in the field. The results are shown in Table 4 which stated the conformity between community rights as outlined in social forestry regulation compared with its implementation in the field. The percentage of conformity is obtained from the number of rights obtained by HKm Beringin Jaya and HTR Hajran in the field compared with the regulation.

The rights of HKm Beringin Jaya and HTR Hajran communities which are stipulated in the social forestry regulation are rights to get facilitation when proposing licence and after obtaining licence as shown in Table 4. In $\mathrm{HKm}$ Beringin Jaya, the rights reached up to $85 \%$, while in HTR Hajran community it only reached $35 \%$. This value indicates that the community of HKm Beringin Jaya has obtained more rights stipulated in the social forestry regulation than the community of HTR Hajran. Thus, the implementation gap of social forestry policy on rights of the licence holder community stipulated in social forestry regulation is higher in HTR Hajran community than in HKm Beringin Jaya community. The results of interviews with key informants of the management and community members of HKm Beringin Jaya, those rights can be obtained because they were facilitated by non-government organization of LCW Lampung when proposing licence and facilitation from non-government organization of KORUT after obtaining the HKm licence. The facilitation provided to community included facilitating the preparation of the conditions needed to propose $\mathrm{HKm}$ licence, providing activities or intervention programs that support the utilization of licence area, increasing the capacity of community members of the HKm Beringin Jaya or bringing resources closer to support community to utilize licence area from stakeholders outside the community. Those facilities

Table 4 Conformity of rights that can be obtained by the community in regulation compared with implementation level of HKm and HTR scheme

\begin{tabular}{|c|c|c|}
\hline \multirow{2}{*}{ Narrative in regulation addresing rights of community } & \multicolumn{2}{|c|}{ Implementation level } \\
\hline & HKm Beringin Jaya & HTR Hajran \\
\hline $\begin{array}{l}\text { Get protection from environmental damage and pollution or takeover } \\
\text { unilaterally by other parties }\end{array}$ & In accordance & No accordance \\
\hline $\begin{array}{l}\text { Manage and utilize licence areas in accordance with local wisdom, } \\
\text { including integrated farming systems }\end{array}$ & In accordance & No accordance \\
\hline Get benefits from genetic resources in the licence area. & In accordance & No accordance \\
\hline Developing a productive economy based on forestry & In accordance & No accordance \\
\hline $\begin{array}{l}\text { Get assistance in the management of licence areas and conflict } \\
\text { resolution }\end{array}$ & In accordance & No accordance \\
\hline Getting partnership assistance in developing its business & In accordance & No accordance \\
\hline Get assistance in preparing annual and general forest management plan & In accordance & In accordance \\
\hline Get fair treatment on the basis of gender or other forms & In accordance & No accordance \\
\hline \multicolumn{3}{|l|}{ Get facilitations: } \\
\hline (1) Proposed proposal & In accordance & In accordance \\
\hline (2) Institutional strengthening & In accordance & In accordance \\
\hline (3) Capacity building including business management & In accordance & No accordance \\
\hline (4) Cooperative establishment & In accordance & In accordance \\
\hline (5) Demarcation of licence area & In accordance & In accordance \\
\hline (6) Composing general and annual work plan & In accordance & In accordance \\
\hline (7) Forms of forestry partnership activities & In accordance & No accordance \\
\hline (8) Financing & In accordance & In accordance \\
\hline (9) Post-harvesting & No accordance & No accordance \\
\hline (10) Business development & No accordance & No accordance \\
\hline (11) Access to market & No accordance & No accordance \\
\hline $\begin{array}{l}\text { Obtain facilitation of programs or activities for forest and land } \\
\text { rehabilitation, soil and water conservation, biodiversity conservation, } \\
\text { empowerment of community-based conservation, certification of } \\
\text { sustainable forest management, timber legality verification }\end{array}$ & $\begin{array}{l}\text { In accordance in term of } \\
\text { rehabilitations of forest and } \\
\text { land, water and soil } \\
\text { conservation, empowerment }\end{array}$ & No accordance \\
\hline Conformity percentage $\mathrm{a}^{\mathrm{a}}$ & $85 \%$ & $35 \%$ \\
\hline
\end{tabular}


are provided by LCW Lampung and KORUT by themselves or by connecting the community to stakeholders who have authorities to grant rights for $\mathrm{HKm}$ Beringin Jaya community.

The facilitation provided by non-governmental organizations has become successful so that the rights are obtained because the Beringin Jaya HKm community is able to organize its members, interact and collaborate among community members and with stakeholders outside the community. This ability is determined by the networking capacity among community members and with stakeholders outside the community (Baynes et al., 2015). Networking capacity is a social capital concept that determines community to take collective action and is useful for community development to achieve community common goals. Networking capacity is formed by good social relationships that are created among community members and with stakeholders outside the community in relation to management of the HKm licence area. In the HTR Hajran community, facilitation from non-governmental organizations only occured when licence is proposed. After obtaining the HTR licence, the community worked with partner company to manage the HTR licence area. With that, the management of the licence area is fully left to partner company. Poor social relations among members of the HTR Hajran community also affect the low networking capacity of the HTR Hajran community.

The results of content analysis of social forestry regulation also showed that the rights of licence holder community from government or non-government institutions are not clearly defined and binding. In social forestry regulation, it is not explicitly addressed who is responsible and has the authority to provide all the rights for a licence holder community, but it can be carried out by the government (central or regional), provincial social forestry working group, forestry extension officer, FMU, related institutions, NGOs, educational agency, primary or secondary wood industry partners owned by the people or companies. Implementation of the policy as a complex system, interventions in one location can provide success that may not be the same as the results in other places (Braithwaite et al., 2018; Allcock et al., 2015), which demands a mutual agreement, coordination, and collaboration to implement on the ground (Kalaba, 2016; McIntyre \& Schultz, 2020). In the HKm Beringin Jaya community, coordination and collaboration at the local level is played by the management and community members of the HKm Beringin Jaya who are facilitated by KORUT to achieve the objectives of social forestry policy, while the government (central-regional) and other stakeholders are used as a complement and part of achieving the destination of the community HKm Beringin Jaya. Apart from the rights of HKm Beringin Jaya and HTR Hajran communities, in social forestry regulation it states that the community has obligations after obtaining HKm and HTR licence. The results of content analysis of social forestry regulations found 8 narratives in the regulations that address these obligations. The criteria used is what narratives in social forestry regulation indicate the obligations of community in implementing the HKm and HTR schemes. This was obtained from a content analysis of social forestry regulation. The comformity between 8 narratives and its implementation in the field is shown in Table 5.

Table 5 shows the conformity between the obligations of community as stipulated in social forestry regulations and its implementation in the field. The percentage of conformity is obtained from the number of obligations fulfilled by $\mathrm{HKm}$ Beringin Jaya and HTR Hajran in the field compared with the

Table 5 Conformity of the obligations that must be fulfilled by the licence holder community in regulation compared with implementation level of the HKm and HTR scheme

\begin{tabular}{|c|c|c|}
\hline \multirow{2}{*}{$\begin{array}{l}\text { Narrative in regulation addressing obligations of } \\
\text { community }\end{array}$} & \multicolumn{2}{|c|}{ Implementation level } \\
\hline & HKm Beringin Jaya & HTR Hajran \\
\hline $\begin{array}{l}\text { Protect the area from environmental damage and } \\
\text { pollution }\end{array}$ & In accordance & $\begin{array}{l}\text { No accordance: illegal logging took } \\
\text { place by unscrupulous members of } \\
\text { the community }\end{array}$ \\
\hline Put a boundary marking of working area & No accordance: natural boundary & No accordance: natural boundary \\
\hline $\begin{array}{l}\text { Prepare a General and Annual Work Plan and } \\
\text { submit an implementation report to the licensor }\end{array}$ & $\begin{array}{l}\text { In accordance } \\
\text { No accordance: Implementation repot } \\
\text { has not submitted }\end{array}$ & $\begin{array}{l}\text { In accordance } \\
\text { No accordance: Implementation } \\
\text { repot has not submitted }\end{array}$ \\
\hline Planting and maintaining forests in working area & $\begin{array}{l}\text { In accordance: dominated by economic } \\
\text { interests }\end{array}$ & $\begin{array}{l}\text { No accordance due to high of } \\
\text { operational costs }\end{array}$ \\
\hline Implement forest product administrative & $\begin{array}{l}\text { In accordance: non-timber forest } \\
\text { products are not required }\end{array}$ & In accordance \\
\hline Paying for the provision of forest resources & $\begin{array}{l}\text { In accordance: non-timber forest } \\
\text { Products are not required paying for } \\
\text { provision }\end{array}$ & In accordance \\
\hline Maintaining the forest function & $\begin{array}{l}\text { In accordance: dominated by economic } \\
\text { interests }\end{array}$ & $\begin{array}{l}\text { No accordance: open access, illegal } \\
\text { logging, land occupation for } \\
\text { gardening }\end{array}$ \\
\hline Implement forest protection & $\begin{array}{l}\text { In accordance: dominated by economic } \\
\text { interests }\end{array}$ & No accordance \\
\hline Conformity percentage & $78 \%$ & $33 \%$ \\
\hline
\end{tabular}


regulation. Obligations that fulfilled by HKm Beringin Jaya and HTR Hajran community are obtained from indepth interviews with key informants and participatory observation in research location. In HKm Beringin Jaya community, the conformity of obligations reached $78 \%$, while in HTR Hajran community it reached 33\%. This percentage indicates that HKm Beringin Jaya community have more fulfilled the obligations stipulated in the regulation than HTR Hajran community. Thus, implementation gap of social forestry policy in terms of obligations is higher in HTR Hajran community than in HKm Beringin Jaya community. The obligations that stipulated in social forestry regulation are mostly fulfilled by the community of HKm Beringin Jaya, which is caused by: (1) there is a clarity and certainty in the utilization and or management of the $\mathrm{HKm}$ licence area for each $\mathrm{HKm}$ member, in the form of agroforest coffee as a source of income. Thus, every member of the HKm Beringin Jaya community follows the obligations so that the HKm licence is not taken back by the government, (2) each HKm member knows and oversees parcels each other's, mutually guarantees and supervises the crops in agroforest coffee, (3) collective rules concerning the rights and obligations to utilize the licence are known by all members, mutually agreed upon and carried out by most HKm members, (4) Management of HKm Beringin Jaya and farmer group supported by the head of village have right to take certain actions if there are $\mathrm{HKm}$ members who violate the collective rules, such as burning, opening new areas outside the HKm licence area, cutting down trees, replacing coffee with seasonal crops or vegetables, stealing crop products, tapping a tree stand or other of violations that might have potential to disrupt the sustainability of utilization and or management of $\mathrm{HKm}$ licence area. Violation by members of $\mathrm{HKm}$ community against the rules of the game that have been mutually agreed upon by the HKm Beringin Jaya community will affect the source of income to those members from the licence area to which they are entitled. Those various things cause each member of the HKm Beringin Jaya community to fulfill mutually agreed obligations in accordance with the obligations stipulated in the social forestry regulation which later turned into collective action of HKm Beringin Jaya community.

In HTR Hajran community, before the HTR licence was obtained, every member of Hajran Village community who would be involved in obtaining the HTR licence had high enthusiasm and motivation. By obtaining HTR licence, community members hope to get improved income. The enthusiasm and motivation decreased after the HTR licence was obtained and its management was carried out through a partnership scheme with a partner company that had just been established to manage the HTR area. Utilization of HTR licence area is carried out jointly or communally, but the majority of decisions on utilization of HTR area are determined by the cooperative management with Partner Company. HTR Hajran members tend to be passive, as if abandoned and there is no clear involvement of HTR members to utilize the HTR area. Interaction between HTR Hajran members with licence area prior to obtaining the HTR licence did not occur excessively, only a few members of Hajran Village community who planted rubber and utilized timber and non-timber forest products from the licence area. The licence area is about $20 \mathrm{~km}$ from settlement of Hajran Village, difficult to pass particularly during rainy season. The initial development of licence area carried out by the partner company only involved a few members of Hajran Village community in technical activities, so that only those members had benefited from the utilization of the HTR area. The partner company only operated for one year and after that went bankrupt because the partner company did not have capacity and adequate resources to manage HTR licence area which contained old forest stands to be converted into community plantation forests. The cooperative's management planned to continue the development of licence area by looking for a new partner company or attracting related stakeholders that could potentially support the utilization and or management of licence area. The cooperative management of HTR Hajran has not planned to organize HTR members to continue the development of the licence area independently due to limited resources they have. The information described above then lead to the failure to fulfill the obligations by HTR Hajran community and partner company regarding the HTR licence area and its management. The obligations stipulated in social forestry regulation are not mostly carried out by the HTR Hajran community. In this situation, intensive facilitation and support from government (central-regional) and related stakeholders is needed to develop the Hajran HTR licence area.

The government and its authorities in implementing social forestry policy In terms of government authorities (central-regional) to implement social forestry policy in HKm and HTR scheme, content analysis found 19 narratives as stipulated in social forestry regulation. The criteria used is the authorities stipulated in social forestry regulation against the government to implement social forestry policy for the HKm and HTR schemes. This is obtained by analyzing the narrative of social forestry regulation which shows the authorities possessed by the government as stipulated in social forestry regulation and by observing how their implementation in HKm Beringin Jaya and HTR Hajran. The comformity between 19 narratives stipulated in social forestry regulation and its implementation in the field is shown in Table 6.

Table 6 shows the conformity between the authorities owned by government (central-regional) as stipulated in social forestry regulation and its implementation in the field. The percentage of conformity is obtained from the number of government authorities carried out in the field compared with the regulation. Government authorities that carried out in implementing social forestry policy were obtained from indepth interviews with key informants and result of participatory observation in research location. The results show that the conformity between government authorities in carrying out social forestry policy stipulated in regulation compared with implementation level reached $36 \%$ in $\mathrm{HKm}$ Beringin Jaya community and $26 \%$ in HTR Hajran community. The percentage of both community is low which indicates the least authority of the government (centralregional) exercised in the field. The authority possessed by the central and regional governments stipulated in social 
Table 6 Conformity of the government to exercise its authority in the legislation compared with implementation level of HKm and HTR scheme

\begin{tabular}{|c|c|c|}
\hline \multirow{2}{*}{$\begin{array}{c}\text { Narrative in regulation addressing government } \\
\text { authorities }\end{array}$} & \multicolumn{2}{|c|}{ Implementation level } \\
\hline & HKm Beringin Jaya & HTR Hajran \\
\hline $\begin{array}{l}\text { Establish indicative maps of social forestry areas } \\
\text { and revise every six months }\end{array}$ & $\begin{array}{l}\text { In accordance: Determination of } \mathrm{HKm} \\
\text { licence area }\end{array}$ & $\begin{array}{l}\text { In accordance: determinatif of HTR } \\
\text { licence area }\end{array}$ \\
\hline $\begin{array}{l}\text { Delegate the determination or rejection of licences } \\
\text { to provincial government (social forestry has been } \\
\text { included in regional medium-term development } \\
\text { plan or a governor regulation and has its budget } \\
\text { in regional revenue and expenditure budget) }\end{array}$ & $\begin{array}{l}\text { In accordance: social forestry has been } \\
\text { included in Provincial Medium-term } \\
\text { Development Plan }\end{array}$ & $\begin{array}{l}\text { In accordance: social forestry has not } \\
\text { been included in Provincial Medium- } \\
\text { term Development Plan or } \\
\text { Governor's regulation }\end{array}$ \\
\hline \multicolumn{3}{|l|}{ Facilitating proposers and licence holders: } \\
\hline (1) Proposed application & NGO & NGO \\
\hline (2) Institutional strengthening & NGO & None \\
\hline $\begin{array}{l}\text { (3) Capacity building including business } \\
\text { management }\end{array}$ & $\mathrm{NGO}$ & None \\
\hline (4) Cooperative establishment & $\mathrm{NGO}$ & NGO \\
\hline (5) Demarcation of licence area & NGO & None \\
\hline (6) Composing general and annual work plan & NGO & $\mathrm{NGO}$ \\
\hline Forms of forestry partnership activities & NGO & Partner company \\
\hline Financial & BRI Bank, BLU-P3H MoEF & BLU-P3H MoEF \\
\hline (9) Post-harvesting & $\begin{array}{l}\text { Indonesian Bank, Ministry of Rural } \\
\text { Development of Disadvantaged Regions } \\
\text { and Transmigration }\end{array}$ & None \\
\hline (10) Business development & NGO & None \\
\hline (11) Access to market & Licence holder & Partner company \\
\hline $\begin{array}{l}\text { Facilitating programs or activities on forest and } \\
\text { land rehabilitation, soil and water conservation, } \\
\text { biodiversity conservation, empowerment of } \\
\text { community-based conservation, certification of } \\
\text { sustainable forest management and or timber } \\
\text { legality certification }\end{array}$ & $\begin{array}{l}\text { BPDAS-HL, KPH: RHL activities } \\
\text { and KTA }\end{array}$ & None \\
\hline $\begin{array}{l}\text { Financing the implementation of social forestry } \\
\text { that can be sourced from the national revenue and } \\
\text { expenditure budget, regional revenue and } \\
\text { expenditure budget, forest development financing } \\
\text { loans, village funds, forest and land rehabilitation } \\
\text { funds and or other legal and non-binding sources } \\
\text { according to regulations }\end{array}$ & NGO, BRI Bank, BLU-P3H MoEF & Partner company, BLU-P3H MoEF \\
\hline $\begin{array}{l}\text { Approve or reject the proposed social forestry } \\
\text { licence }\end{array}$ & In accordance & In accordance \\
\hline $\begin{array}{l}\text { Evaluate the implementation of social forestry by } \\
\text { the licence holder every } 5 \text { years }\end{array}$ & None & None \\
\hline $\begin{array}{l}\text { Provide administrative sanctions to licence holders } \\
\text { if found to have violated or failed to fulfill the } \\
\text { obligations }\end{array}$ & None & None \\
\hline $\begin{array}{l}\text { Revoke or extend a social forestry licence after an } \\
\text { evaluation }\end{array}$ & None & None \\
\hline Conformity percentage & $37 \%$ & $26 \%$ \\
\hline
\end{tabular}

forestry regulation which is implemented inadequately at the field level causes the communities of HKm Beringin Jaya and HTR Hajran to seek stakeholders or other parties who can assist and facilitate them when proposing licence or after obtaining licence. Most of activities that should be under the authority of government to facilitate the HKm Beringin Jaya and HTR Hajran community were provided by nongovernmental organizations. Government authorities that are actually exercised by the government in the research location are the determination of HKm and HTR licence area ${ }^{2}$, issuance of $\mathrm{HKm}$ Beringin Jaya licence by the Bupati of Tanggamus and HTR Hajran licence by the Head of the Regional Investment Board and Integrated Licensing Services of Jambi Province, and loan financing from Public Service Agency for the Centre of Forest Development Financing (Badan Layanan Umum Pusat Pembiayaan Pembangunan Hutan/BLU-P3H), MoEF. Most of preparations and requirements that must be met in order to obtain those matters under the authority of the government, mostly carried out by the HKm Beringin Jaya and HTR

${ }^{2}$ In current social forestry regulation, prospective social forestry licence areas are summarized in Indicative Map of Social Forestry Areas (Peta Indikatif Areal Perhutanan Sosial/PIAPS). 
Hajran community which are facilitated by nongovernmental organization. The central and regional governments act more as stakeholders who must be visited or accessed by the licence holder community in exercising their authority. The government has not yet reached the stage of facilitating licence holder community as stipulated in social forestry regulation.

The community of HKm Beringin Jaya which has high network capacity is able to access other activities or programs under the authority of the central and regional governments. Government activities or programs that have successfully accessed by the community of HKm Beringin Jaya include: 1) program of forest and land rehabilitation, soil and water conservation by the Lampung BPDAS-HL together with FMU, 2) the facilitation of post-harvesting tool of coffee beans from Indonesian Bank (already operational) and Ministry of Rural Development of Disadvantaged Regions and Transmigration (not yet operational, constrained by building infrastructure, electricity, financial and management groups), and 3) financing loans from BRI Bank. All of this information was obtained from in-depth interviews with key informants from members and management of the $\mathrm{HKm}$ Beringin Jaya as well as the results of field participatory observations. Social forestry is a policy set by the central government to be implemented at the local level. With a separate political system and authority between the central and regional governments, the successful implementation of social forestry policy is influenced by coordination and collaboration between the central and regional governments and support from regional government in exercising their authority to facilitate license holder community in their respective region. The government referred to social forestry regulation are MoEF and Technical Implementation Unit in province and district, National and Provincial Social Forestry Working Group, FMU, Forestry Extension officers, and other public services at provincial and district level. In social forestry regulation, the division of authority between central and regional governments to facilitate community is very clearly described at the stages of issuing HKm and HTR licence. In the post-licensing stage, the division of authority between central and regional governments to facilitate community is not detailed and explained. It only states that the government can facilitate the licence holder community after obtaining the licence in utilizing or managing the licence area. The office of social forestry and environmental partnerships is technical implementation unit that is responsible for implementing social forestry policy in the regions, but its role in facilitating community of HKm Beringin Jaya and HTR Hajran is not found in the field.

In both research locations, the FMU at site level closest to community, has not yet become a government agency discussing problems and solutions in implementing social forestry policy. The role of FMU in the implementation of social forestry is limited by the authority in legislation and limited funding that causes the low capacity of FMU and their functions to be optimal as managers of state forest areas at the site level (Wira, 2019). The research results on $\mathrm{HKm}$ Beringin Jaya community showed that despite the limited capacity of FMU and local government support in the field, the community of HKm Beringin Jaya can achieve social forestry policy objectives by collaborating with nongovernmental organizations. Collaboration with nongovernmental organizations is carried out by facilitating the community to propose licence and utilize licence areas to achieve the benefits intended by community under the implementation of social forestry policy. Facilitation is also carried out to access resources, activities or programs under the authority of the central and regional governments so that the central and regional governments are willing to accommodate and support the efforts of the HKm Beringin Jaya community.

With regard to these matters, the FMU at site level was firmly assigned by the national government as the main implementing agency for social forestry policy. Supriyanto (2019) stated that the government and apparatus in the field should behave and work in providing facilitation and assistance to the community, as one of the determinants of the successful implementation of social forestry policy. However, some people who work in frontline agency are not effective in implementing policy because they are not in fit with their interests and agendas (Spillane et al., 2002). This relates to the nature of their work and thus ignores policy, partly because of the erratic relationships they may have with service users (communities or private sectors) or the lack of close scrutiny of their actions (Spillane et al., 2002). Thus McLaughlin (1987) stated that the individual or person responsible for carrying out policy implementation is not only due to institutional incentives, but also from professional and personal motivation. Increasing the capacity of the central and local government officials so that they are able to facilitate community is one of the main keys to achieving the objectives of social forestry policy. Policy makers at the national and subnational levels should properly promote partnerships between organizations, and improve patchwork (Gazley, 2017), coordination in implementing policy (Kalaba, 2016; McIntyre \& Schultz, 2020). Policy design requires continuous collaboration with various stakeholders at various political levels, policy makers, managerial and administration, as well as the involvement of local actors implementing "downstream" such as end users, frontline staff and other various local service agents (Hudson et al., 2019). Ansell et al. (2017) emphasize the need for policy designed in such a way that they connect actors vertically and horizontally in the process of collaboration and joint deliberation. The design and implementation of policy becomes an integrated process rather than a series of different and separate phase, although policy makers are equipped with the necessary skills, competencies, capacities, and abilities to overcome systemic weaknesses and succeed in these efforts as another matter (Williams, 2012).

Related stakeholders and their involvements in support social forestry implementation In terms of related stakeholders and their involvement in support social forestry policy implementation in HKm and HTR scheme, content analysis found 11 narratives as stipulated in social forestry regulation. The criteria used to identify the involvement of related stakeholders are narratives in social forestry regulations that show the facilitation that can be carried out by related stakeholders to support the community in implementing social forestry policy in HKm and HTR 
schemes. At the field level, it is then explored who related stakeholders are involved in providing facilitation to the community of HKm Beringin Jaya and HTR Hajran in implementing social forestry scheme as stipulated in the social forestry regulation. Related stakeholders referred to social forestry regulation include NGO, Universities, primary or secondary timber industry partners owned by the people or companies. Related stakeholders defined in social forestry regulation and their involvement in supporting the implementation of social forestry policy found in $\mathrm{HKm}$ Beringin Jaya and HT Hajran community are shown in Table 7

In HKm Beringin Jaya, NGO involvement reached 64\%, financing from BRI Bank and BLU-P3H, MoEF reached 9\%, tool of post-harvesting of coffee bean assisted by Indonesian Bank and Ministry of Rural Development of Disadvantaged Regions and Transmigration reached $9 \%$ and none of related stakeholders involved amounted to $18 \%$. In HTR Hajran, NGO involvement reached $36 \%$, financing from BLU-P3H, MoEF reached $9 \%$, forestry partnership activities by Partner Company reached $9 \%$ and none of related stakeholders involved amounted to $45 \%$. The percentage value is calculated from the number involvement of related stakeholders in facilitating the community of HKm Beringin Jaya and HTR Hajran in the pre-licence and post-licence stages as outlined in the social forestry regulation. Data and information about the involvement of related stakeholders in facilitating the community of HKm Beringin Jaya and HTR Hajran were obtained from the results of in-depth interviews with key informants and participatory field observation in the two research locations. Based on the percentage value of the involvement of related stakeholders in the two research locations, non-governmental organizations are related stakeholders whose involvement is higher than other related stakeholders. The involvement of non-governmental organizations in facilitating the community of $\mathrm{HKm}$ Beringin Jaya was higher than that of the HTR Hajran community.

The involvement of other related stakeholders is related to community efforts to utilize and manage the licence area in the form of financial loans, tools assistance and partnerships to manage the licence area. In terms of business development and access to markets (large trader or company), none of the related stakeholders were found in facilitating the community of HKm Beringin Jaya and in HTR Hajran. In HKm Beringin Jaya community, secondary productive venture of agroforest coffee that producing variety of products is still limited. The Himawari group produces various products of coffee at household level, while access to central markets or big traders/companies has not yet occurred. This is caused by the large number of community members and agricultural product traders at the village who are connected to provincial and national markets. In HTR Hajran community, productive economic activities did not occur, either by the community or carried out by partner company in licence area. Partner company did not continue to manage HTR licence area because their businesses in managing HTR licence area went bankrupt. After the partner company stopped their activities, none of related stakeholders facilitated the HTR Hajran community.The related stakeholders that support the implementation of social forestry policy in HKm Beringin Jaya and HTR Hajran communities do not simply provide something or resources (programs, financial, information, skills, capacity building or others) that they control, but the community should have access to those related stakeholders, carried out independently or facilitated by NGO. The resources that have been obtained are then used to support the productive venture so that the intended benefits of $\mathrm{HKm}$ Beringin Jaya and HTR Hajran community are obtained.

Table 7 Related stakeholders ${ }^{\mathrm{a}}$ and their involvement in the implementation of social forestry policy of in HKm and HTR scheme

\begin{tabular}{lll}
\hline \multirow{2}{*}{$\begin{array}{c}\text { Narrative in regulation addressing related stakeholders } \\
\text { involvement }\end{array}$} & \multicolumn{1}{c}{ Implementation level } \\
\cline { 2 - 3 } Proposed application & NGO & HTR Hajran \\
Institutional strengthening & NGO & None \\
Capacity building including business management & NGO & None \\
Cooperative establishment & NGO & NGO \\
Demarcation of licence area & NGO & NGO \\
Composing general and annual work plan & NGO & NGO \\
Forms of forestry partnership activities & NGO & Partner company \\
Financial & BRI Bank, Public Service Agency & Public Service Agency \\
& for the Centre for Forest & for the Centre for \\
& Development Financing (BLU- & Forest Development \\
& P3H) & Financing (BLU-P3H) \\
Post-harvesting & Indonesian Bank, Ministry of & None \\
& Rural Development of & \\
& Disadvantaged Regions and & \\
Business development & Transmigration & None \\
Access to market & None & None \\
& None & \\
a Related stakeholders referred to narrative in social forestry regulation include NGO, Universities, primary or secondary timber industry \\
partners owned by the people or companies.
\end{tabular}


Those something or resources owned or controlled by related stakeholders because of the capacity and authority of related stakeholders so they own and controll the resources. When the resources are delivered to licence holder community, it then provides institutional incentives (McLaughlin, 1987) to related stakeholders (fiscal or non-fiscal) (Enters, 2004). In this situation, a mutually beneficial relationship occurs and can take place continuously if there is a good social relationship between the licence holder community and the related stakeholders. In reality, not all of licence holder communities have capacity to do so, so the involvement of the related stakeholders based on their own capacities in supporting community to utilize and manage social forestry licence areas which creates mutual benefits must be encouraged by central and regional government. Social forestry regulation formulated by the national government applied at local level equally, but the achievement of policy objectives by one to another licence holder community can be different (Braithwaite et al., 2018; Allcock et al., 2015), with respect to political authority in the regions (Norris et al., 2014; Kalaba, 2016). The regional government at provincial or district level can be a facilitator or mediator to create an intented situation in achieving the objectives of social forestry policy through regional policy and its instruments. Thus, in addition to requiring the involvement of related stakeholders to support the community, implementation of social forestry policy requires the central and regional governments to be able to create profitable mechanisms (fiscal or non-fiscal) that can attract the attention of related stakeholders so that they are triggered to be involved in facilitating and supporting the community to achieve the objectives of social forestry policy.

\section{Conclusion}

Research on implementation gap of social forestry policy concluded that there is a gap in the implementation of social forestry policy towards the stakeholders stipulated in social forestry regulation to implement social forestry policy. In two research locations, the rights and the obligations of licence holder communities were mostly facilitated by nongovernmental organizations, only to a lesser extent by the central and local governments and other related stakeholders. Apart from being facilitated, the number of rights obtained and obligations fulfilled by the licence holder community according to those stipulated in social forestry regulation is influenced by network capacity possessed by licence holder community. The authority of central and regional governments stipulated in social forestry regulation to facilitate licence holder community is exercised inadequate at the field level due to the separate political system and authority between central and regional governments, requiring coordination and synergy and policy implementor with professional motivations and high personality. FMU is not yet optimal as the government institution closest to community to facilitate community in implementing social forestry policy. Apart from non-governmental organizations, the involvement of other related stakeholders in facilitating community license holders is low. Resources owned by related stakeholders can be obtained by the community if the community has the capacity to access them and the interests of these stakeholders are accommodated when facilitating the community. Thus, the objectives of social forestry policy can be achieved by the community as the main subject if the authorities of central and regional governments exercised adequately at the field level and there is involvement of related stakeholders. For this reason, in addition to the community who must have the capacity in pre and post licence phase, the implementation of social forestry policy also demands the capacity of central and regional governments in accordance with their authorities and requires the involvement of related stakeholders to support and faciliate the community.

\section{Recommendation}

The successful implementation of social forestry policy is determined by the low implementation gap of the community, central and local governments and related stakeholders stipulated in the social forestry regulations to implement policy that are highly dependent on the local context. To reduce this gap, this study recommends that the community holders of HKm and HTR licence, local governments and related stakeholders at the local level synergize and collaborate with their respective roles that are adapted to local context.

\section{Acknowledgment}

The article is part of dissertation of Graduate Program of Forest Management Science, Faculty of Forestry and Environment, IPB University, funded by the Environment and Forestry Education and Training Centre. Thanks to the Head of Enviroment and Forestry Education and Training Centre, Ministry of Environment and Forestry Republic of Indonesia, for providing research funding support.

\section{References}

Agung, R., Rahayu, Y., Saputro, T., Tjandrakirana, R., Ramdhany, D., Wibawa, W., ..., \& Muttaqin, M. Z. (2018). Status hutan dan kehutanan Indonesia 2018. Jakarta: Kementerian Lingkungan Hidup dan Kehutanan.

Ansell, C., Sørensen, E., \& Torfing, J. (2017). Improving policy implementation through collaborative policymaking. Policy and Politics, 45(3), 467-486. https://doi.org/10.1332/030557317X14972799760260

Allcock, C., Dorman, F., Taunt, R., \& Dixon, J. (2015). Constructive comfort: Accelerating change in the NHS. London: The Health Foundation. Retrieved from https://www.health.org.uk/sites/default/files/Constructi veComfortAcceleratingChangeInTheNHS.pdf

Ardi. (2011). Pengembangan institusi pengelolaan hutan tanaman rakyat pola agroforestri (Studi kasus Lamban Sigatal, Kabupaten Sarolangun Jambi) [dissertation]. Bogor: IPB University.

Basrin, E. (2017). Pengembangan ekonomi berbasis masyarakat melalui ragam inovasi dan investasi UMKM kehutanan. In Kumpulan naskah akademik konferensi 
tenurial 2017 (pp. 137-160). Jakarta.

Baynes, J., Herbohn J., Smith, C., Fisher, R., \& Bray, D. (2015). Key factors which influence the success of community forestry in developing countries. Global Enviromental Change, 35, 226-238. https://doi.org/ 10.1016/j.gloenvcha.2015.09.011

Birner, R. (2000). Analytical methods in the social science. Gottingen: Gottingen University.

Braithwaite, J., Churruca, K., Long, J. C., Ellis, L. A., \& Herkes, J. (2018). When complexity science meets implementation science: A theoretical and empirical analysis of systems change. BMC Medicine, 16, 63. https://doi.org/10.1186/s12916-018-1057-z

de Royer, S., Juita, R., Galudra, G., \& Pradhan, U. (2015). Are village forest licences for rural development or conservation? A case study from Jambi Province, Indonesia (ICRAF Brief No. 53). Bogor: World Agroforestry Centre. Retrieved from http://www.worldagroforestry.org/publication/arevillage-forest-licences-rural-development-orconservation-case-study-jambi-province

de Royer, S. \& Juita, R. (2016). Village forest licences (Hutan Desa) in West Kalimantan: Way forward for equity and land security? (ICRAF Brief No. 58). Bogor: World Agroforestry Centre. Retrieved from http://www.worldagroforestry.org/publication/villageforest-licences-hutan-desa-west-kalimantan-wayforward-equity-and-land-security

Dunn, W. N. (2003). Pengantar analisis kebijakan public (edisi 2). Yogyakarta: Universitas Gadjah Mada.

Enters, T. (2004). Incentives: Key concepts, typology and rationale. In T. Enters, \& P. B. Durst (Eds.), What does it take? The role of incentives in forest plantation development in Asia and the Pacific. Bangkok: Asian Pasific Forestry Commission.

Franks, R. P., \& Bory, C. T. (2015). Who supports the successful implementation and sustainability of evidence-based practices? Defining and understanding the roles of intermediary and purveyor organisations. New Directions for Child and Adolescent Development, 149, 41-56. https://doi.org/10.1002/cad.20112

Gazley, B. (2017). The current state of interorganizational collaboration: Lessons for human service research and management. Human Service Organizations: Management, Leadership and Governance, 41(1), 1-5. https://doi.org/10.1080/23303131.2015.1095582

Hudson, B., Hunter, D., \& Peckam, S. (2019). Policy failure and the policy-implementation gap: Can policy support programs help? Policy Design and Practice, 2(1), 1-14. https://doi.org.10.1080/25741292.2018.1540378

Kalaba, F. K. (2016). Barriers to policy implementation and implications for Zambia's forest ecosystem. Forest Policy and Economics, 69, 40-44. https://doi.org/10.016/ j.forpol.2016.04.004

Kartodihardjo, H., Nugroho, B., Rohadi, D., Suharjito, D., \& Dermawan, A. (2011). Community plantation forests in Indonesia: Challenges and policy recommendations (CIFOR Brief No. 42.) Bogor: Centre for International Forestry Research. Retrieved from https://www.cifor.org/publications/pdf files/infobrief/ 3666-infobrief.pdf

Kartodihardjo, H. (2017a). Dibalik krisis ekosistem: Pemikiran tentang kehutanan dan lingkungan hidup. Bogor: LP3ES and Yayasan Kehati.

Kartodihardjo, H. (2017b). Analisis kebijakan pengelolaan sumberdaya alam: Diskursus politik, aktor, jaringan. Bogor: Firdaus, Sajogjo Institute, Yayasan Auriga, RMI, P4W-IPB and PSA-IPB.

Kirsop-Talyor, N. A. (2018). Street level influences affecting implementation of an ecosystem approach within the North Devon UNESCO Biosphere Reserve [dissertation]. Devon: University of Exeter. Retrieved from https://ore.exeter.ac.uk/repository/bitstream/ handle $/ 10871 / 37385 /$ Kirsop-TaylorN.pdf? sequence $=1$ \&isAllowed $=\mathrm{y}$

[KORUT] Konsorsium Kota Agung Utara. (2017). Pengembangan sistem pengelolaan informasi pengelola hutan kemasyarakatan (HKm) di Kabupaten Tanggamus Lampung. Lampung: KORUT, TFCA Sumatera dan Universitas Lampung.

McIntyre, K. B. \& Schultz, C. A. (2020). Facilitating collaboration in forest management: Assesing the benefits of collaborative policy innovations. Land Use Policy, 96. https://doi.org/10.1016/j.landusepol.2020. 104683

McLaughlin, M. W. (1987). Learning from experience: Lessons from policy implementation. Educational Evaluation and Policy Analysis, 9(2), 171-178. https://doi.org/10.2307/1163728

[MoEF] Ministry of Environment and Forestry. (2017). Statistik lingkungan hidup dan kehutanan tahun 2017. Jakarta: Ministry of Environment and Forestry.

Norris, E., Kidson, M., Bouchal, P., \& Rutter, J. (2014). Doing them justice: Lessons from four cases of policy implementation. London: Institute for Government. Retrieved from https://www.instituteforgovernment .org.uk/sites/default/files/publications/Policy\%20Imple mentation $\% 20$ case $\% 20$ studies $\% 20$ report $\% 20$ $\% 20$ final.pdf

[PEW] Pew Charitable Trust. (2017). Four ways implementation support centers assist in the delivery of evidence-based programmes. Philadephia: The Pew Charitable Trust. Retrieved from https://www. 
pewtrusts.org/-/media/assets/2017/08/results_4_ways implementation_support_centers_assist_ in_the_delivery_of_evidence_based_programs.pdf

Roberts, N. C. \& King, P. J. (1996). Transforming public policy: Dynamics of policy entrepreneurship and innovation. San Fransisco: Josey-Bass.

Santoso, T. (2019). Lima hutan, satu cerita. Jakarta: Yayasan Perkasa Hijau.

Sausman, C., Oborn, E., \& Barrett, M. (2016). Policy translation through localisation: Implementing national policy in the United Kingdom. Policy and Politics, 44(4), 563-589. https://doi.org/10.1332/030557315X1429 8807527143

Spillane, J. P., Reiser, B. J., \& Reimer, T. (2002). Policy implementation and cognition: Reframing and refocusing implementation research. Review of Educational Research, 72(3), 387-431. https://doi.org/ $10.3102 / 00346543072003387$

Suharto, E. (2010). Analisis kebijakan publik: Panduan praktis mengkaji masalah dan kebijakan sosial. Bandung: Alfabeta.
Supriyanto, B., Karyana, A., Rosdiana, E., Tjiptono, B. H., Dwiyati, N., Prasetiani, C. E. P., ..., \& Haryanto, G. (2018). Dampak perhutanan sosial: Perspektif ekonomi, sosial, dan lingkungan. Jakarta: Kementerian Lingkungan Hidup dan Kehutanan.

Supriyanto, B. (2019). Catatan dari tepi hutan. Jakarta: Tempo Publishing.

Syafitri, M. A. (2010). Forest tenure in Indonesia: The sociolegal challenges of securing communities'right [dissertation]. Leiden: Leiden University. Retrieved from https://openaccess.leidenuniv.nl/handle/ 1887/16242

Titscher, S., Mayer, M., Wodak, E., \& Vetter, E. (2009). Metode analisis teks dan wacana. Yogyakarta: Pustaka Pelajar.

Wira, F. (2019). Peran kesatuan pengelolaan hutan (KPH) dalam implementasi perhutanan sosial (studi di KPH Produksi Kerinci, Provinsi Jambi dan KPH Lindung Sijunjung, Provinsi Sumatera Barat) [thesis]. Bogor: IPB University.

Williams, P. (2012). Collaboration in public policy and practice. Bristol: Bristol University Press. Retrieved from https://doi.org/10.2307/j.ctt1t89g31 